\title{
Experimental and mathematical simulation study on the granulation of a modified BOF steel slag
}

Chunwei Liu, Pavel Leonardo Lopez Gonzalez, Shuigen Huang, Yiannis Pontikes, Bart Blanpain, Muxing Guo

Department of Materials Engineering, KU Leuven, Kasteelpark Arenberg 44, BE3001 Leuven, Belgium

\begin{abstract}
Basic oxygen furnace (BOF) steel slag is a major by-product generated from steelmaking industry. Recycling of BOF slag contributes to the sustainability of steel industry by alleviating its environmental impact. Vitrification is an effective method to promote the cementitious activity of slags with the aim to apply slags in high value-added applications. In the present study, a $\mathrm{Al}_{2} \mathrm{O}_{3}$ and $\mathrm{SiO}_{2}$ modified $\mathrm{BOF}$ slag was water granulated at a pilot scale. The amorphous and mineral fractions were measured quantitatively. The critical cooling rate to vitrify the modified slag was calculated through the constructed TimeTemperature-Transformation (TTT) diagrams using in-situ confocal scanning laser microscope (CSLM) observation. To provide an insight into the crystallization behavior during the granulation process, a mathematical model was developed. The model was validated by comparing the amorphous fraction obtained from experiments with that from simulation. Temperature profiles of the slag particles with varied sizes were calculated with the aid of COMSOL Multiphysics software. The effect of particle size on the vitrified fraction was discussed in detail and the temperature gradient from surface to center of the particle was identified. The results provide fundamental understanding of the vitrification process, which will help the industrial implementation of slag vitrification.
\end{abstract}

Key words: BOF Slag; Critical cooling rate; Simulation; Vitrification; 


\subsection{Introduction}

Steel slag is a main residue produced in the steel industry. Around $100-150 \mathrm{~kg}$ slag is discharged for producing 1 tonne steel[1]. Basic oxygen furnace (BOF) slag represents a major portion of steel slag, and it originates from the external fluxes (burnt lime or dolomite) and oxidation of impurities in the hot metal during the converter steelmaking process[2]. Associated with the large steel production, approximately 10 million tonnes BOF slag is generated annually according to the EUROSLAG Association[3]. Storage of the BOF slag not only causes a substantial financial burden to steel industry, but also triggers environmental concerns due to the potential leaching of heavy metals, such as $\mathrm{V}, \mathrm{Cr}$ and $\operatorname{Mn}[4]$.

Recycling of slags as a secondary resource, alternatively, contributes to the sustainable development of steel industry and the environment. BOF slag is a $\mathrm{CaO}$-rich silicate system in general, and it could be re-used in cement applications [5-7], concrete aggregate[8], road construction[9,10] and as metallurgical fluxing agent[11]. Although high value-added applications such as cement appear to be more interesting, large-scale application of the BOF slag has been limited to the metallurgical fluxing agent due to its volume expansion[12]. The disintegration of bulk slags is caused by the hydration of free lime and magnesia (mainly free lime) in the slag[13], which exhibits around 10 pct swelling[9]. Therefore, the chemical composition and cooling path should be modified to prevent volume instability of the slag and to improve its hydraulic/cementitious potential. $\mathrm{SiO}_{2}$ and $\mathrm{Al}_{2} \mathrm{O}_{3}$ have been reported as effective modifiers to stabilize the BOF slag[14]. The addition of $\mathrm{SiO}_{2}$ results in more silicate, which binds the free $\mathrm{CaO}$ into calcium silicates. The addition of $\mathrm{Al}_{2} \mathrm{O}_{3}$ produces more calcium aluminoferrite (formular $\mathrm{Ca}_{2}(\mathrm{Al}, \mathrm{Fe})_{2} \mathrm{O}_{5}$, in short $\mathrm{C}_{2} \mathrm{AF}$ ) by combining with free lime[15-19]. In addition to modifying the chemical composition, rapid cooling to form glass phase is an effective method to enhance the potential as binder or added-value applications[20]. Ferreira Neto et al. investigated the effects of $\mathrm{SiO}_{2}$ and $\mathrm{Al}_{2} \mathrm{O}_{3}$ on the cementitious property of a steel slag under different cooling conditions. It was concluded that $\mathrm{SiO}_{2}$ and $\mathrm{Al}_{2} \mathrm{O}_{3}$ additions promotes vitrification of the BOF slag by fast cooling[21]. However, it has not been determined yet under what conditions the slag can be vitrified. Moreover, it is not clear how the slag temperature 
changes during the granulation process. This information is essential to be able to develop the granulation process.

The present work aims to investigate the vitrification of an $\mathrm{Al}_{2} \mathrm{O}_{3}$ and $\mathrm{SiO}_{2}$-modified $\mathrm{BOF}$ slag through pilot scale granulation and mathematical simulation. The mineralogical composition of the modified BOF slag after granulation are characterized. The critical cooling rate to vitrify the slag is obtained through the calculation combined with the measured TTT diagrams. A mathematical model is developed to quantitatively determine the temperature profiles during granulation. The model is validated by comparing the measured glass fraction with that of simulation. Thereafter, the effect of particle size on the vitrification is discussed.

\subsection{Experimental procedure and mathematical simulation}

\subsubsection{Granulation of a modified BOF slag at a pilot scale}

An industrial BOF slag was premixed with secondary $\mathrm{Al}_{2} \mathrm{O}_{3}$ and $\mathrm{SiO}_{2}$-riched materials at a mass ratio that was determined by the preliminary lab scale experiments. The scale-up furnace is able to melt $1,500 \mathrm{~kg}$ slag at approximately $1400{ }^{\circ} \mathrm{C}$. After holding for 3 hours to homogenize the chemical composition, the molten slag was tapped out and immediately granulated by water. The granulated slags with various particle sizes were eventually collected and analyzed. The chemical composition of the slag after granulation was measured by X-Ray Fluorescence (XRF, Panalytical PW 2400), as given in Table 6.1.

Table 6.1. Chemical composition of the granulated slag (in mass pct).

\begin{tabular}{llllllllll}
\hline Total $\mathrm{Fe}$ & $\mathrm{CaO}$ & $\mathrm{SiO}_{2}$ & $\mathrm{Al}_{2} \mathrm{O}_{3}$ & $\mathrm{MgO}$ & $\mathrm{MnO}$ & $\mathrm{TiO}_{2}$ & $\mathrm{~V}_{2} \mathrm{O}_{5}$ & $\mathrm{ZrO}_{2}$ & $\mathrm{Cr}_{2} \mathrm{O}_{3}$ \\
\hline 16.17 & 37.38 & 17.93 & 11.89 & 4.78 & 2.18 & 1.09 & 0.50 & 0.27 & 0.19 \\
\hline
\end{tabular}

\subsubsection{Evaluation of the transition and nose temperature of the modified BOF slag}

In-situ CSLM observation was used to estimate the liquidus $\left(T_{l},{ }^{\circ} \mathrm{C}\right)$ and solidus $\left(T_{s},{ }^{\circ} \mathrm{C}\right)$ temperature of the modified slag. The CSLM combines the advantages of confocal optics and a He-Ne laser, thereby making it possible to observe samples at high resolution at elevated temperatures. The temperature calibration and technical description of the set-up were reported in our previous work[22,23]. Figure 6.1 (a) shows the corresponding 
temperature profile. The slag was heated up to $1673 \mathrm{~K}$ in air at a rate of $200 \mathrm{~K} \cdot \mathrm{min}^{-1}$ and kept at that temperature for $5 \mathrm{~min}$ to homogenize the slag composition. Then the slag was cooled to $1200{ }^{\circ} \mathrm{C}$ at a rate of $5{ }^{\circ} \mathrm{C} \mathrm{min}{ }^{-1}$, followed by a rapid cooling at $200{ }^{\circ} \mathrm{C} \mathrm{min}^{-}$ 1. Consequently, the liquidus and solidus temperature of the crystallization $\left(T_{o}^{1}\right.$ and $\left.T_{e}^{1}\right)$ can be estimated. The temperature, where the first crystal formation was detected, is considered to be the liquidus temperature. The temperature from which the crystal stops growing are considered as the solidus temperature.

Nose temperature, which delineates the minimum time for developing the detectable crystallinity[24], is a key value to calculate the critical cooling rate to vitrify the melt. To measure the nose temperature, the TTT diagram was constructed by in-situ CSLM observation of the slag crystallization. The temperature profile employed to construct the TTT diagram is shown schematically in Figure 6.1 (b). A tiny amount of slag $(\sim 0.1 \mathrm{~g})$ was placed on a Pt holder and heated up at $200{ }^{\circ} \mathrm{C} \mathrm{min}$ m $^{-1}$ to $1500{ }^{\circ} \mathrm{C}$ in air. The molten slag was kept at $1500{ }^{\circ} \mathrm{C}$ for $5 \mathrm{~min}$ to homogenize the slag composition. Thereafter, the slag was cooled rapidly to a desired temperature ranging from 1240 to $1290{ }^{\circ} \mathrm{C}$. The slag was kept at that temperature and the onset and ending temperature of the crystallization was recorded.

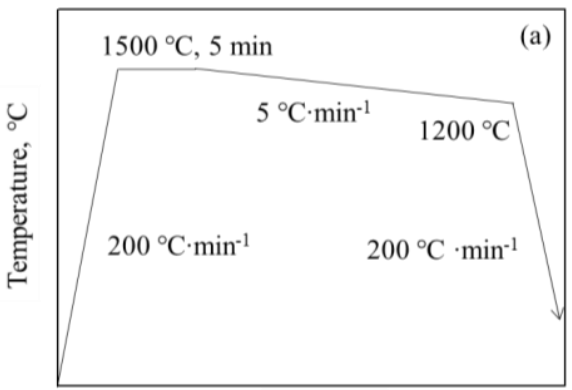

Time, $\mathrm{s}$

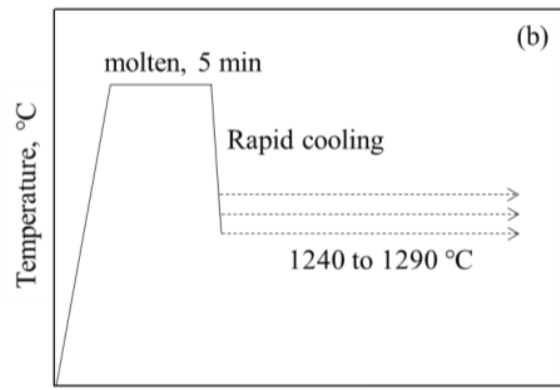

Time, $\mathrm{s}$

Figure 6.1. Schematic diagram of the temperature profile (a) to determine liquidus and solidus temperature (b) to measure the TTT diagram

\subsubsection{Characterization}

To quantitatively measure the amorphous content in the granulated slag, the slag was milled to a size less than $100 \mu \mathrm{m}$ and wet-mixed with $10 \mathrm{wt}$ pct $\mathrm{ZnO}$ powder (purity 99.9 pct, Sigma-Aldrich BVBA, Belgium), which was added as a standard reference. Then mineral and amorphous fractions in the granulated slag were identified by X-Ray Diffraction (XRD, D2 Phaser, Bruker, Germany), with $2 \theta$ in the range of $5-70^{\circ}$ using $\mathrm{Cu}$ 
$\mathrm{K} \alpha$ radiation at $30 \mathrm{kV}$ and $10 \mathrm{~mA}$. The step size was $0.02^{\circ}$ scanning within 0.6 second. Quantitative analysis of the XRD (QXRD) result was achieved through Rietveld refinement.

The slag specimens were mounted in a low viscosity resin (Epoxy), ground by silicon carbide papers and polished with diamond paste. The polished specimens were coated with carbon for compositional and microstructural analyses by using electron probe microanalysis (EPMA, JXA-8530F, JEOL Ltd, Japan). The accelerating voltage was set at $15 \mathrm{kV}$ and a beam current was $15 \mathrm{nA}$ used.

\subsubsection{Fundamentals of Modelling of the Pilot Granulation}

The calculated domain and boundary conditions are schematically illustrated in Figure 6.2. To simplify the calculation, the following assumptions were considered:

(a) A single slag droplet with spherical shape is considered and it is fixed at the center of the domain;

(b) Incompressible water flow is at steady state with a flow rate of $1 \mathrm{~m} \cdot \mathrm{s}^{-1}$. The outlet of the water flow is at zero pressure.

(c) Liquid water is considered to be opaque to thermal radiation, i.e., no radiation is considered in the calculation.

(d) No-slip adiabatic boundary conditions are enforced on all external walls of the device.

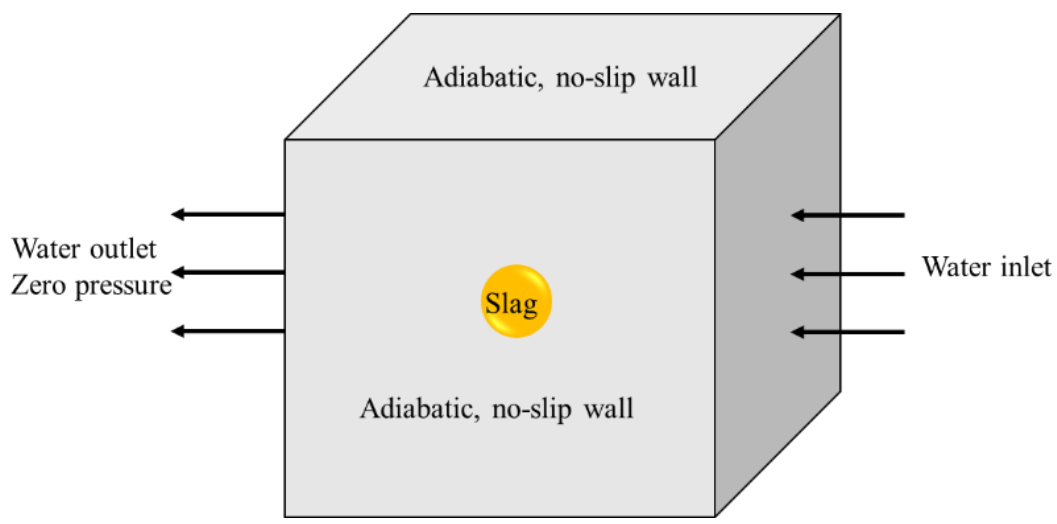

Figure 6.2. Schematic presentation of the calculated domain and boundary conditions 
Based on the above assumptions, the heat transfer in the slag and that in water during the granulation process are respectively governed by Eqs. (6.1-1) and (6.1-2)[25]

$$
\begin{gathered}
C_{p} \rho \frac{\partial T}{\partial t}=k \nabla^{2} T+\emptyset \\
C_{p}^{\prime} \rho^{\prime} \frac{\partial T^{\prime}}{\partial t}=C_{p}^{\prime} \rho^{\prime} v \nabla T^{\prime}+k^{\prime} \nabla^{2} T^{\prime}
\end{gathered}
$$

where $C_{p}\left(\mathrm{~J} \cdot \mathrm{kg}^{-1} \cdot \mathrm{K}^{-1}\right)$ and $\rho\left(\mathrm{kg} \cdot \mathrm{m}^{3}\right)$ are, respectively the heat capacity and density of the slag; $T\left({ }^{\circ} \mathrm{C}\right)$ is the temperature of the slag; $t(\mathrm{~s})$ is the granulation time; $v\left(\mathrm{~m} \cdot \mathrm{s}^{-1}\right)$ is the water flow rate; $k\left(\mathrm{~W} \cdot \mathrm{m}^{-1} \cdot \mathrm{K}^{-1}\right)$ is the thermal conductivity of the slag; $\varnothing\left(\mathrm{W} \cdot \mathrm{m}^{-3}\right)$ is the volumetric heat generation rate of phase transition (crystallization). Accordingly, symbols with a comma as superscript refer to the corresponding physical property of water. The temperature field and the heat flux are continuous at the slag/water interface.

Latent heat $(Q, \mathrm{~J})$ generated during crystallization can be calculated as

$$
Q=\int_{T_{1}}^{T_{2}} C_{p} d T
$$

where $T_{2}$ and $T_{1}$ are, respectively the onset and ending temperatures of the crystallization; the heat capacity of the slag during the crystallization can be obtained through Eq. (6.3)[25].

$$
C_{p}=\frac{1}{\rho}\left[\phi \rho_{\text {solid }} C_{p_{\text {solid }}}+(1-\phi) \rho_{\text {liquid }} C_{p_{\text {liquid }}}\right]
$$


where $\phi$ (pct) is the solidified fraction of the slag during the crystalliation process; $C_{p_{\text {solid }}}\left(\mathrm{J} \cdot \mathrm{kg}^{-1} \cdot \mathrm{K}^{-1}\right)$ and $C_{p_{\text {liquid }}}\left(\mathrm{J} \cdot \mathrm{kg}^{-1} \cdot \mathrm{K}^{-1}\right)$ are the heat capacity of solid and liquid slag respectively; $\rho_{\text {solid }}$ and $\rho_{\text {liquid }}\left(\mathrm{kg}^{-1} \cdot \mathrm{m}^{3}\right)$ are the density of the solid and liquid slag. Density of the whole partile can be calculated as

$$
\rho=\phi \rho_{\text {solid }}+(1-\phi) \rho_{\text {liquid }}
$$

Heat capacities of the liquid and solid slag are obtained from Ref[26]. The parameters used in the model is shown in Table 6.2.

Table 6.2. Parameters used in the present modelling by COMSOL Multiphysics software.

\begin{tabular}{l|lc}
\hline \multirow{3}{*}{$\begin{array}{l}\text { Phase 1 } \\
\text { (Liquid slag) }\end{array}$} & Density, $(\rho, \mathrm{kg} / \mathrm{m} 3)$ & 2804 \\
& Heat capacity, $(\mathrm{Cp}, \mathrm{J} /(\mathrm{kg} \cdot \mathrm{K})$ & $1400[26]$ \\
& Thermal diffusivity, $\left(\alpha, \mathrm{m}^{2} / \mathrm{s}\right)$ & $1.27 \times 10^{-7}[28]$ \\
& Thermal conductivity, $(\mathrm{k}, \mathrm{W} /(\mathrm{m} \cdot \mathrm{K}))$ & $0.4[29,30]$ \\
\hline \multirow{3}{*}{ Phase 2 } & Density, $(\rho, \mathrm{kg} / \mathrm{m} 3)$ & $3650[31]$ \\
(Solidified slag) & Heat capacity, $(\mathrm{Cp}, \mathrm{J} /(\mathrm{kg} \cdot \mathrm{K})$ & $1200[26]$ \\
& Thermal diffusivity, $(\alpha, \mathrm{m} 2 / \mathrm{s})$ & $4.6 \times 10^{-7}[32]$ \\
& Thermal conductivity, $(\lambda, \mathrm{W} /(\mathrm{m} \cdot \mathrm{K})$ & $2[27]$ \\
\hline \multirow{2}{*}{ Phase transition } & Liquidus temperature, ${ }^{\circ} \mathrm{C}$ & 1330 \\
& Solidus temperature, ${ }^{\circ} \mathrm{C}$ & 1260 \\
\hline
\end{tabular}

The Eq. (6.1) was numerically solved by means of the Finite Element (FE) softwareCOMSOL Multiphysics. It combines heat transfer with the fluid flow (water jet). This provides a proper way to evaluate the temperature profiles during water granulation with respect to various slag particle sizes. The initial conditions are given in Eq. (6.5).

$$
\begin{gathered}
T_{\text {water }}=20^{\circ} \mathrm{C} \\
T_{\text {slag }}=1400^{\circ} \mathrm{C}
\end{gathered}
$$

Discretization of the calculated domain into finite elements was performed by an unstructured meshing.

\subsection{Results and discussion}

\subsubsection{Pilot experiment}


The overall amorphous and mineralogical contents in the modified BOF slag after granulation are given in Figure 6.3. 53.4 wt pct amorphous phase was measured. In addition to the amorphous phase, the main minerals observed in the samples are respectively dicalcium silicate $\left(\mathrm{Ca}_{2} \mathrm{SiO}_{4}\right.$, in short $\left.\mathrm{C}_{2} \mathrm{~S}\right)$, tricalcium aluminate $\left(\mathrm{Ca}_{3} \mathrm{Al}_{2} \mathrm{O}_{6}\right.$, in short $\left.\mathrm{C}_{3} \mathrm{~A}\right)$ and iron oxides $\left(\mathrm{Fe}_{3} \mathrm{O}_{4}\right.$ and $\left.\mathrm{Fe}_{2} \mathrm{O}_{3}\right)$. The large fraction of amorphous phase indicates that granulation is an effective method to partially vitrify the modified BOF slag. Figure 6.4 shows the microstructure of the granulated slag. A nearly fully amorphous granule is shown in Figure 6.4 (a). In the meanwhile, in other granules, small sized crystalline phases can be observed and are scattered in the amorphous granule matrix, as seen in Figure 6.4 (b). The slag granules with spherical shape and small size suggests that the modified BOF slag has been atomized after hitting the water during the granulation. Due to the large specific surface area of the small slag droplets, this granulation may maximize the cooling rate of the slag particles under a certain water flow. Figure 6.4 (c) and (d) represent the typical morphology of the granulated slag in more detail. The amorphous phase represents the slag matrix, in which there are crystalline phases precipitated during the granulation, such as $\mathrm{C}_{3} \mathrm{~A}$ (darker crystal), $\mathrm{C}_{2} \mathrm{~S}$ (concave shape) and iron oxides $\left(\mathrm{FeO}_{x}\right.$, bright crystal), as identified by WDS analysis. The large area fraction of amorphous phase observed in the backscattered electron (BSE) images (Figure 6.4) agrees well with the QXRD analysis of the slag samples. It is concluded that the slag has been broken down to small particles and vitrified at a fair level during the water granulation process. 
Chapter 6. Simulation of granulation

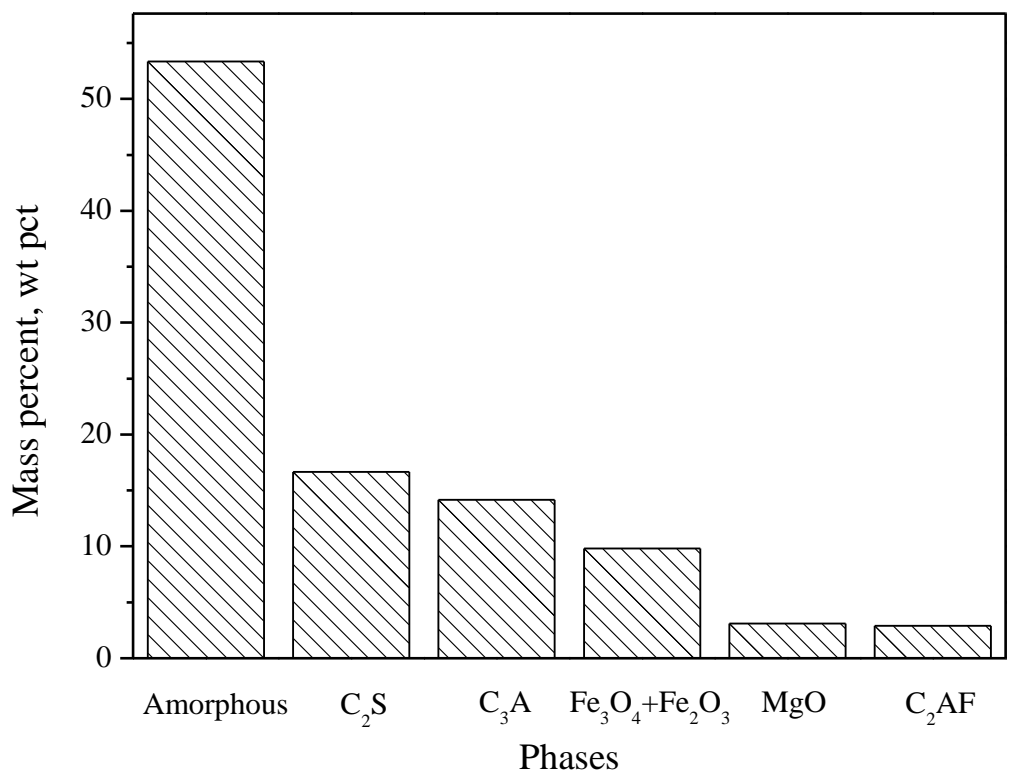

Figure 6.3. Mass percentage of the phases in the modified BOF slag after granulation, as quantified with Rietveld refinement
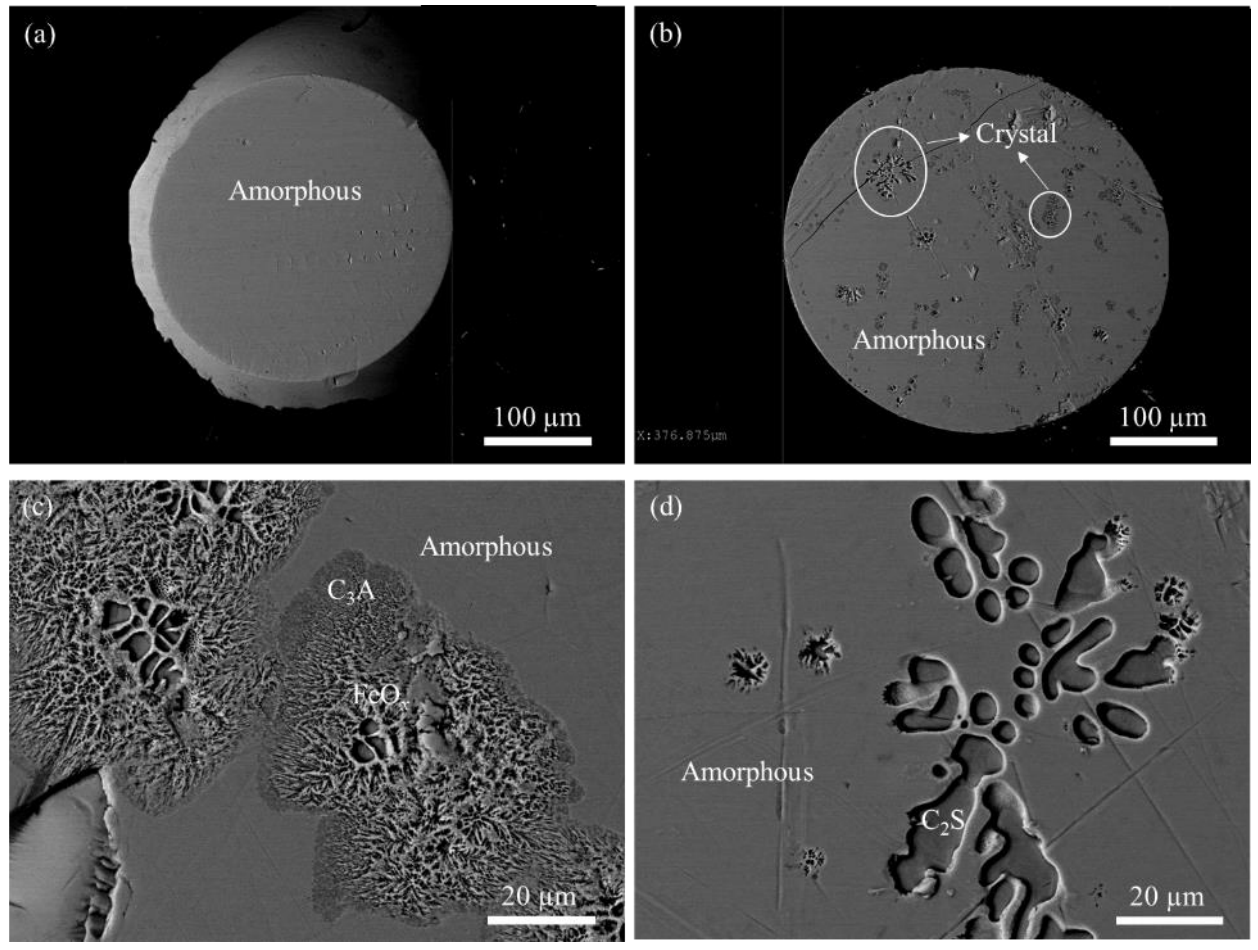
Figure 6.4. Typical microstructure of the modified slag after granulation. (a) A typical amorphous granule; (b) A typical crystal-containing granule; (c) Morphology of $\mathrm{C}_{3} \mathrm{~A}$ and $\mathrm{FeO}$; (d) Morphology of $\mathrm{C}_{2} \mathrm{~S}$

\subsubsection{Critical Cooling Rate to Vitrify the Modified BOF Slag: in-situ Observation and Calculation}

In principle, all materials can form glasses during cooling from a liquid state at the moment when the viscosity of the liquid reaches $10^{13} \mathrm{~Pa} \cdot \mathrm{s}$. At the corresponding temperature, e.g. glass transition temperature, the mobility of the structural units is insufficient to be arranged in a crystal[33]. In this study, $1295{ }^{\circ} \mathrm{C}$ is assumed as the glass transition temperature, which is the midpoint between $T_{l}$ and $T_{S}$.

Figure 6.5 shows TTT diagram of the modified BOF slag, where a classical C shape curve was identified. By decreasing the isothermal temperature, the incubation time for crystallization was decreased significantly. The critical part of TTT diagram is the nose region, which is determined to be $1240{ }^{\circ} \mathrm{C}$.

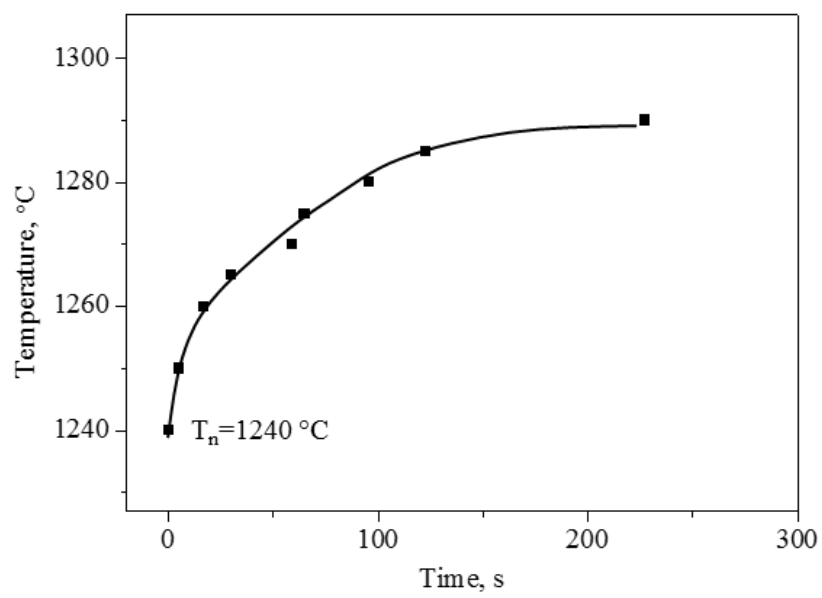

Figure 6.5. TTT diagrams of the modified BOF slag solidification in air (measured by the CSLM test). $T_{n}$ is the nose temperature

When the cooling rate is higher than critical cooling rate $\left(R_{c}\right)$, amorphous phase will be formed. Otherwise, crystalline phase will be precipitated[34]. Therefore, $R_{c}$ is of significant importance to evaluate the glass formation ability of a melt. Based on the 
fundamentals of the crystallization kinetics, Uhlmann and Onoratoo developed a model to estimate the critical cooling rate $\left(R_{C}\right)$ for glass formation[24]:

$$
R_{c}=\frac{A T_{l}^{2}}{\eta_{n}} \exp (-0.212 B)\left[1-\exp \left(\frac{-0.3 \Delta S_{m}}{R}\right)\right]^{3 / 4}
$$

where $A=40,000 \mathrm{~J} \cdot \mathrm{m}^{-3} \cdot \mathrm{K}^{-1}$ is a constant; $T_{l}\left({ }^{\circ} \mathrm{C}\right)$ is the liquidus temperature of the slag; $\eta_{n}$ $(\mathrm{Pa} \cdot \mathrm{s})$ is the viscosity at the nose temperature; $B$ refers to the kinetic barrier to form a critical nucleus $\left(B \approx 12.6 \times\left(\Delta S_{m} / R\right)\right.$ at a relative undercooling of $(\Delta \mathrm{T} / \mathrm{T})$ of 0.2 , where $\Delta \mathrm{T}$ is the undercooling of the slag during crystallization) $[35,36] ; \Delta S_{m}\left(\mathrm{~J} \cdot \mathrm{K}^{-1} \cdot \mathrm{mol}^{-1}\right)$ is the fusion entropy of the slag. This model has been successfully applied to estimate $R_{c}$ of the slag in recent years[37,38].

Among those parameters in Eq. (6.6), $B$ and $\Delta S_{m}$ can be determined using FactSage 7.1. $T_{l}$ can be estimated by in-situ CSLM observation of the slag. Since $\eta_{n}$ is difficult to be measured experimentally due to the rapid crystallization characteristic of BOF slag, it is determined in this work by FactSage calculation using the measured nose temperature of the slag. Table 6.3 presents values of the parameters employed for determining the critical cooling rate $\left(R_{c}\right)$ of the glass formation. $R_{c}$ is determined to be $2700{ }^{\circ} \mathrm{C} \cdot \mathrm{s}^{-1}$.

Table 6.3. Parameters used to calculate the critical cooling rate to vitrify the modified BOF slag

\begin{tabular}{ccccc}
\hline$T_{l},{ }^{\circ} \mathrm{C}$ & $T_{n},{ }^{\circ} \mathrm{C}$ & $\eta_{n}, \mathrm{~Pa} \cdot \mathrm{s}$ & $\Delta S_{m}, \mathrm{~J} \cdot \mathrm{K}^{-1} \cdot \mathrm{mol}^{-1}$ & $R_{c},{ }^{\circ} \mathrm{C} \cdot \mathrm{s}^{-1}$ \\
\hline 1330 & 1240 & 0.295 & 55.3 & 2700 \\
\hline
\end{tabular}

\subsubsection{Mathematical simulation on the granulation of a modified BOF slag}

The present pilot-scale slag granulation was simulated using COMSOL with respect to the changes in slag granule temperature as a function of granulation time and position within a slag particle. To vitrify the slag, the slag should be cooled down from $1400{ }^{\circ} \mathrm{C}$ (tapping temperature) to $1295{ }^{\circ} \mathrm{C}$ (glass transition temperature) at a cooling rate higher than $2700{ }^{\circ} \mathrm{C} \cdot \mathrm{s}^{-1}\left(R_{c}\right)$, which takes $0.0387 \mathrm{~s}$. Thus, the slag which could be cooled down to lower than $1295{ }^{\circ} \mathrm{C}$ within $0.0387 \mathrm{~s}$ is able to form glass phase and avoid the slag 
crystallization. For a particle with a given size, the temperature at $0.0387 \mathrm{~s}$ as a function of position within a slag particle can be calculated via COMSOL. All the particles are assumed to have a spherical shape and its density change during the phase transition is ignored. As a consequence, the vitrification fraction (defined by Eq. (6.7)) can be calculated.

$$
\varphi=\frac{V_{1}}{V_{2}}
$$

where $V_{1}$ the volume of the glass phase and $V_{2}$ the total slag volume.

Figure 6.6 (a) shows the calculated effect of particle size on the vitrification at cooling rate of $2700{ }^{\circ} \mathrm{C} \mathrm{s}^{-1}$. For comparison, the experimental data were also plotted in the figure as indicated by the brackets. Clearly, the amorphous fraction decreased appreciably upon increasing the particle size. To validate this mathematical simulation, the granulated slag from the pilot experiment was sieved and characterized. The amorphous contents in different size ranges were measured by the QXRD. As seen in Figure 6.6 (a), the amorphous fractions are 78.2, 51.2, and 20.9, respectively for the particles ranging from 0.08 to $0.8 \mathrm{~mm}, 0.8$ to $2.5 \mathrm{~mm}$ and larger than $4 \mathrm{~mm}$. The calculated fractions for the 0.8 , 2.5 and $4 \mathrm{~mm}$-sized particles are respectively 85.9, 36.4 and 29.0 pct. Correspondingly, for the particles below $0.8 \mathrm{~mm}$, the amorphous fractions is above $85.9 \mathrm{pct}$; for the particles ranging from 0.8 to $2.5 \mathrm{~mm}$, this fraction is from 36.4 to $85.9 \mathrm{pct}$; for the particles larger than $4 \mathrm{~mm}$, this fraction is below 29.0 pct. The simulated results agree well with the measured ones. Therefore, the present model can be applied to simulate the pilot scale water granulation of the modified BOF slag.

As indicated in Figure 6.6 (a), the critical particle size to fully vitrify the slag is calculated to be $0.5 \mathrm{~mm}$. A larger particle size implies a less than fully amorphous structure. For the $1 \mathrm{~mm}$-sized particles, the amorphous fraction is $76.9 \mathrm{pct}$, but it drops to 31.2 and $29.0 \mathrm{pct}$ for particles with diameters of 3 and $4 \mathrm{~mm}$. But the decreasing rate of amorphous fraction slows down with further increasing particles size. The variation of amorphous fraction with particle size can be also described by the change of the ratio of the vitrified thickness to particle diameter. As shown in Figure 6.6 (b), for particles smaller than $2 \mathrm{~mm}$, the ratio decreased rapidly, followed by a slow decrease in the ratio with further increasing particle size. The amorphous fraction of $2 \mathrm{~mm}$-sized particles is calculated as 51.2 pct. "AM" in Figure 6.6 (b) indicates the amorphous-dominated region, where the amorphous fraction is 
larger than that of crystalline fraction. This particle size effect can be attributed to the heat transfer. A larger particle implies more heat (both latent and sensible) to be evacuated, and the heat transfer by conduction inside a larger particle is relatively smaller than that in a smaller particle due to a lower temperature gradient and a smaller surface to volume ratio.

In order to obtain the amorphous-dominated solid slag, it is suggested to atomize liquid slag to particle size less than $2 \mathrm{~mm}$.
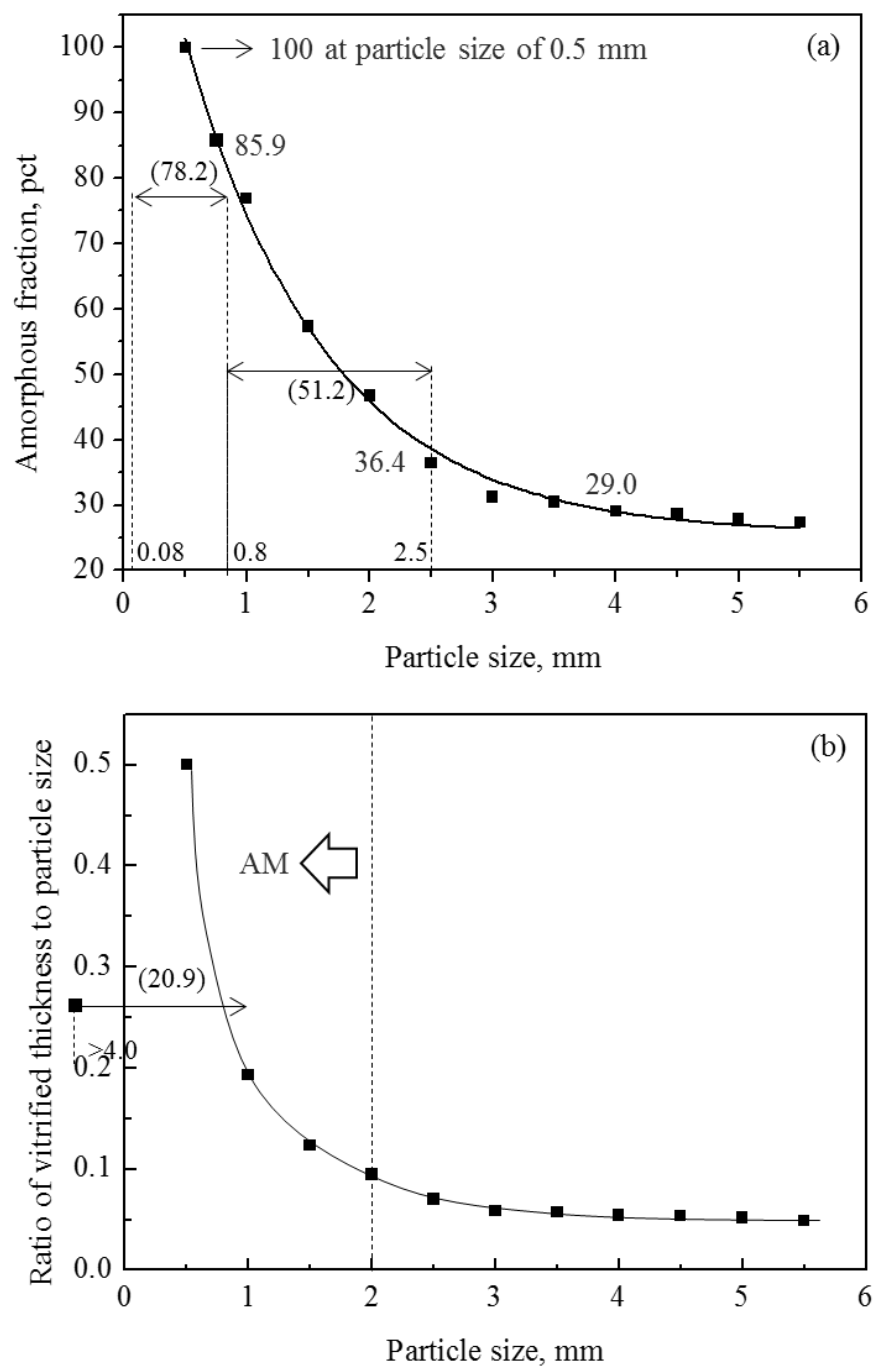
Figure 6.6. (a) Effect of particle size on the amorphous fraction. The curve is regressed based on simulated result. The values with brackets are measured result, others are calculated result. (b) Ratio of the vitrified thickness to the particle size, as COMSOL simulated. "AM" represent the amorphous-dominated region
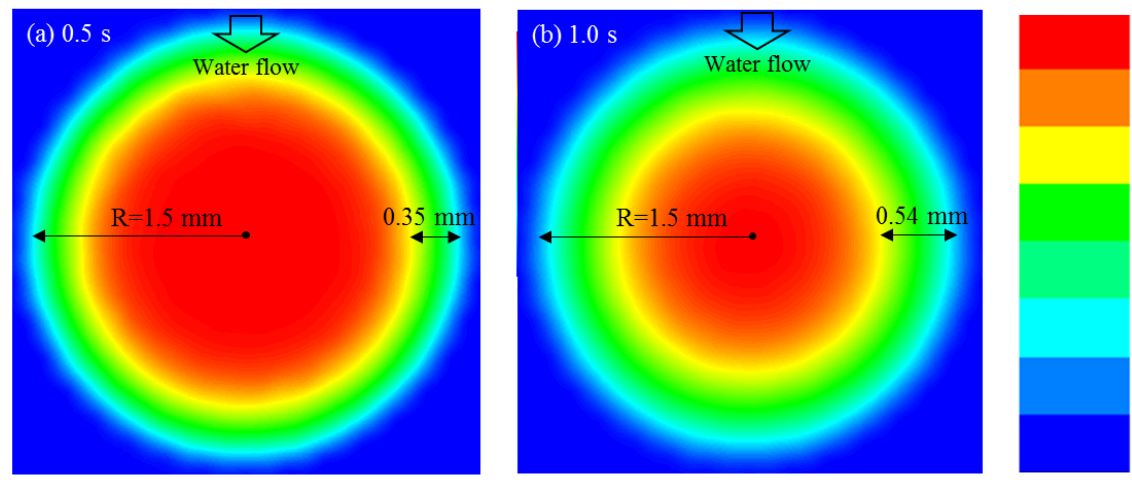

$1407^{\circ} \mathrm{C}$

Figure 6.7. Temperature contours of the granulated slag with a diameter of $3 \mathrm{~mm}$ after (a) $0.5 \mathrm{~s}$ and (b) $1.0 \mathrm{~s}$, respectively. The slice contains the center of the particle and is parallel to the water flow direction

Temperature contours of the water granulated slag can be calculated as functions of granulation time and particle size. Figure 6.7 (a) and (b) take a 3-mm sized particle respectively after water quenching of $0.5 \mathrm{~s}$ and $1.0 \mathrm{~s}$ as an example. The selected slice passes through the center of the particle and is parallel to water flow direction. The calculated results in Figure 6.7 suggest that a large temperature gradient forms inside the slag particle during the granulation. By comparing the contours at $0.5 \mathrm{~s}$ and $1.0 \mathrm{~s}$, it is found that the thickness of lower-temperature range $\left(<1060{ }^{\circ} \mathrm{C}\right.$, indicated by the doubleheaded arrows) increases with time. After $0.5 \mathrm{~s}$, the lower-temperature thickness is approximately $0.35 \mathrm{~mm}$, while it increases to $0.54 \mathrm{~mm}$ after $1.0 \mathrm{~s}$. In addition, the temperature contours are nearly symmetric, meaning that the water flow direction has a minor influence on the temperature distribution. 


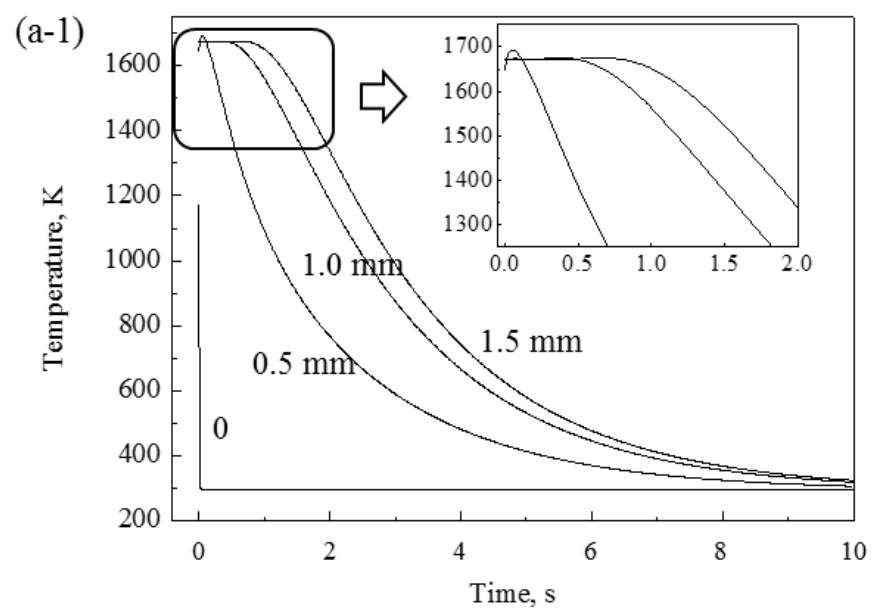

(a-2)

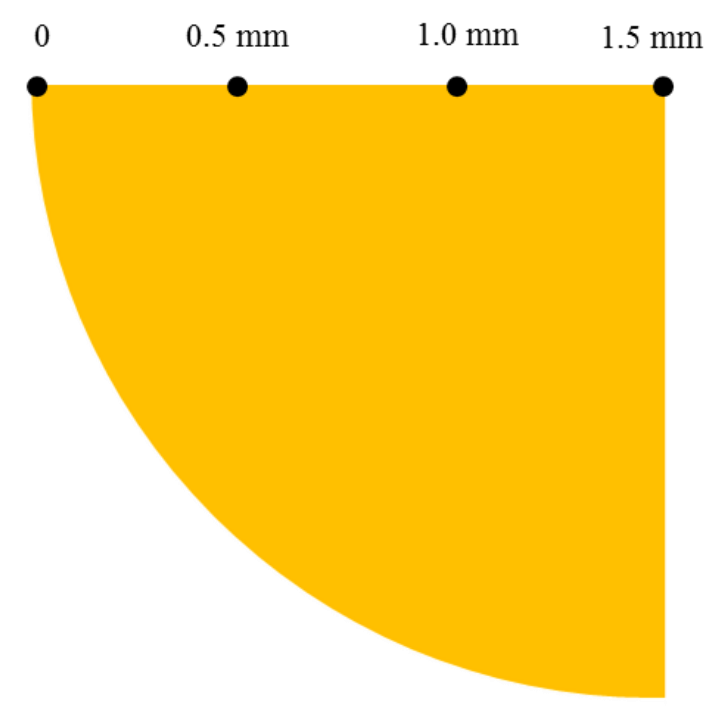




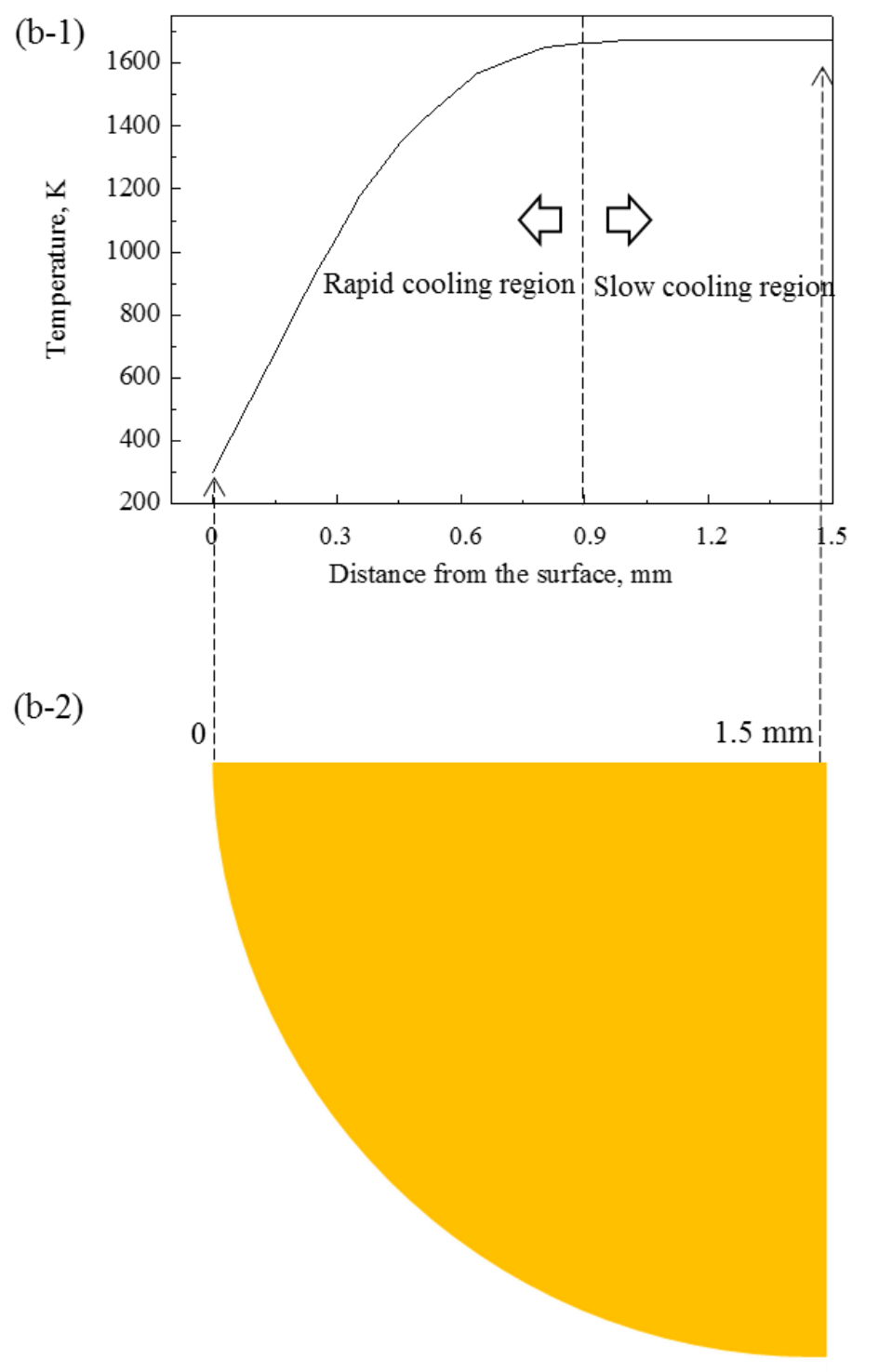

Figure 6.8. (a) Temperature evolution with granulation time at different positions in a 3 mm-sized particle; (b) Temperature profile as a function of positions at $0.5 \mathrm{~s}$ after granulation in a $3 \mathrm{~mm}$-sized particle. The distance is measured from the slag surface.

The calculated temperature profiles at different positions in a $3 \mathrm{~mm}$-sized particle are given in Figure 6.8. Since the temperature contour is almost symmetric regardless of the water 
flow direction (see Figure 6.7), only a quarter of the particle is considered. Figure 6.8 (a1) shows the temperature evolution within $10 \mathrm{~s}$ after granulation at various positions which are indicated in Figure 6.8 (a-2). The distance is measured from the slag surface. The slag surface experienced a rapid cooling, and the temperature decreased to less than $20^{\circ} \mathrm{C}$ within $0.01 \mathrm{~s}$ (Figure $6.8(\mathrm{a}-1)$ ). The temperature profile, however, varied markedly with the distance from particle surface. It takes $4.11 \mathrm{~s}$ to cool down the slag below $200{ }^{\circ} \mathrm{C}$ at the position of $0.5 \mathrm{~mm}$, while it takes 5.63 and $6.05 \mathrm{~s}$ for the slag at the positions of 1.0 and $1.5 \mathrm{~mm}$ (center) respectively. It is noteworthy that at the position of $0.5 \mathrm{~mm}$ the temperature firstly increases, and then decreases, as shown by an embedded figure in Figure 6.8 (a-1). The slight increase of temperature at the beginning of the granulation is attributed to the latent heat released during crystallization, which can be calculated via Eqs. (6.2) and (6.3). When the latent heat generation is larger than the heat loss by water cooling, the temperature is expected to be increased. Figure 6.8 (b) shows the temperature profile from surface to center of the particle at $0.5 \mathrm{~s}$ was given in Figure 6.8 (b). Temperature changes from 20 to $1397{ }^{\circ} \mathrm{C}$ from the surface to $0.9 \mathrm{~mm}$, while it keeps approximately at 1397 to $1407{ }^{\circ} \mathrm{C}$ from 0.9 to $1.5 \mathrm{~mm}$ (center). Thus, the solidification of the slag can be divided into rapid cooling and slow cooling regions. A significant temperature difference between the particle surface and center has been observed in Figure 6.9 (b). It is evident that after $0.5 \mathrm{~s}$ water quenching the surface temperature of the granule is comparable to the ambient temperature $\left(20^{\circ} \mathrm{C}\right)$, but the core of the slag particle is still very hot $\left(\mathrm{T}>1295^{\circ} \mathrm{C}\right)$. As a result, it will be not possible to completely vitrify a $3 \mathrm{~mm}$-sized particle within 0.5 second.

Therefore, it is key to atomize the slag melt into smaller particles (due to the large surface/volume ratio, balls are preferable) during the granulation process, because a smaller particle size gives a faster cooling rate. The slag property (e.g. viscosity, surface tension) and water flow property (e.g. rate, injection direction) might play an important role in smashing/crushing the slag, but the details need further clarification.

\subsection{Conclusions}

Pilot scale granulation, in-situ CSLM observation and mathematical simulation have been performed to investigate the vitrification behavior of a modified BOF slag. After water 
granulation, the amorphous fraction and minerals composition of the slag were analyzed by QXRD. TTT diagram of the modified BOF slag was constructed. The critical cooling rate to vitrify the modified BOF slag was obtained through FactSage calculation and CSLM observation. Mathematical simulation was then developed and solved with the aid of COMSOL Multiphysics. The model was validated by comparing the measured glass fraction with that of simulation. The effect of particle size on formation of amorphous fraction was revealed. This study provides a fundamental understanding on granulation process. The main conclusions are summarized as follows.

(1) In the current water granulation at a pilot scale, a $\mathrm{SiO}_{2}$ and $\mathrm{Al}_{2} \mathrm{O}_{3}$-modified BOF slag yields $53.4 \mathrm{wt}$ pet amorphous fraction. Microstructural analysis confirms that the amorphous phase represents the slag matrix, in which there are crystalline phases precipitated during the granulation, such as $\mathrm{C}_{3} \mathrm{~A}, \mathrm{C}_{2} \mathrm{~S}$ and iron oxides.

(2) The incubation time reaches the shortest at $1240{ }^{\circ} \mathrm{C}$ under the isothermal solidification. The critical cooling rate to vitrify the modified BOF slag is determined to be $2700{ }^{\circ} \mathrm{C} \cdot \mathrm{s}^{-1}$.

(3) The present simulation is valid to predict the temperature evolution during granulation. Temperature profiles as a function of position within a slag particle were calculated via COMSOL. The particle size has a key influence on the cooling rate and the critical size to completely vitrify the modified slag is $0.5 \mathrm{~mm}$. A large temperature gradient from surface to center of the slag particle was identified. 


\section{References}

[1] D. M. Proctor, K. A. Fehling, E. C. Shay, J. L. Wittenborn, J. J. Green, C. Avent, R. D. Bigham, M. Connolly, B. Lee, T. O. Shepker, and M. A. Zak: Environ. Sci. Technol., 2000, vol. 34, pp. 1576-82.

[2] E. T. Turkdogan and R. J. Fruehan: in Fundam. Iron Steelmak., 11th ed., Association of Iron and Steel Engineers, Pittsburgh, 1998, p. 160.

[3] www.euroslag.com, accessed on 10/4/2017.

[4] H. Motz and J. Geiseler: Waste Manag., 2001, vol. 21, pp. 285-93.

[5] T. S. Zhang, Q. J. Yu, J. X. Wei, J. X. Li, and P. P. Zhang: Resour. Conserv. Recycl., 2011, vol. 56, pp. 48-55.

[6] G. Wimmer, H. Wulfert, H.M. Ludwig, and A. Fleischanderl: in METEC 2nd Eur. Steel Technol. Appl. Days, 2015, pp. 1-6.

[7] A. Srinivasa Reddy, R. K. Pradhan, and S. Chandra: Int. J. Miner. Process., 2006, vol. 79, pp. 98-105.

[8] Y. J. Xue, S. P. Wu, H. B. Hou, and J. Zha: J. Hazard. Mater., 2006, vol. 138, pp. 261-68.

[9] S. A. Mikhail and A. M. Turcotte: Thermochim. Acta, 1995, vol. 263, pp. 87-94.

[10] J. Murphy, T. Meadwcroft, and P. Barr: Can. Metall. Q., 1997, vol. 6, pp. 315-31.

[11] G. Z. Ye, E. Burstr, M. Kuhn, and J. Piret: Scand. J. Metall., 2003, vol. 32, pp. 714.

[12] J. N. Murphy, T. R. Meadowcroft, and P. V. Barr: Can. Metall. Q., 1997, vol. 36, pp. 315-31.

[13] R. M. Santos, D. Ling, A. Sarvaramini, M. X. Guo, J. Elsen, F. Larachi, G. Beaudoin, B. Blanpain, and T. Van Gerven: Chem. Eng. J., 2012, vol. 203, pp. 239-50.

[14] J. A. Duffy, M. D. Ingram, and L. D. Sommerville: J. Chem. Soc. Faraday Trans. 1 Phys. Chem. Condens. Phases, 1978, vol. 74, pp. 1410-19.

[15] B. Deo, J. Halder, B. Snoeijer, A. Overbosch, and R. Boom: Ironmak. Steelmak., 2005, vol. 32, pp. 54-60.

[16] C. W. Liu, M. X. Guo, L. Pandelaers, B. Blanpain, and S. G. Huang: in Adv. Molten Slags, Fluxes, Salts Proc. 10th Int. Conf. Molten Slags, Fluxes Salts, 2016, pp. 1185-90.

[17] X. R. Wu, P. Wang, L. S. Li, Z. J. Wu, and R. H. Chen: Ironmak. Steelmak., 2011, vol. 38, pp. 185-88.

[18] V. Z. Serjun, B. Mirtic, and A. Mladenovic: Mater. Tehnol., 2013, vol. 47, pp. 543-50.

[19] D. Ionescu, T. R. Meadowcroft, and P. V. Barr: Adv. Cem. Res., 2001, vol. 13, pp. 21-30.

[20] L. Kriskova, Y. Pontikes, L. Pandelaers, Ö. Cizer, P.T. Jones, K. Van Balen, and B. Blanpain: Metall. Mater. Trans. B, 2013, vol. 44, pp. 1173-84.

[21] J. B. Ferreira Neto, J.O.G. Faria, C. Fredericci, F.F Chotoli, A.N.L. Silva, B.B. Ferraro, T. R Ribeiro, A. Malynowskyj, V. A. Quarcioni, and A. A Lotto: J. Sustain. Metall., 2016, vol. 2, pp. 13-27.

[22] J. J. Liu, G. Chen, P. C. Yan, B. Blanpain, N. Moelans, and M. X. Guo: Am. J. Sci., 2014, vol. 402, pp. 1-8.

[23] J. J. Liu, M. X. Guo, P. T. Jones, F. Verhaeghe, B. Blanpain, and P. Wollants: J. Eur. Ceram. Soc., 2007, vol. 27, pp. 1961-72. 
[24] D. R. Uhlmann and P. I. K. Onoratoo: in 10 Th Proc. Lunar Planet. Sci. Conf., 1979, pp. 375-81.

[25] R. B.ron Bird, W. E. Stewart, E. N. Lightfoot: Transport Phenomena, illustrate, John Wiley \& Sons, 2007, 2007.

[26] K. C. Mills: South. African Pyrometallurgy 2011 Int. Conf., 2011, pp. 1-52.

[27] R. Eriksson, and S. Seetharaman: Metall. Mater. Trans. B, 2004, vol. 35, pp. 46169.

[28] Y.J. Kang and K. Morita: ISIJ Int., 2006, vol. 46, pp. 420-26.

[29] Y. Kang, K. Nomura, K. Tokumitsu, and H. Tobo: Metall. Mater. Trans. B, 2012, vol. 43B, pp. 1420-1426.

[30] M. Tossavainen, F. Engstrom, Q. Yang, N. Menad, M. Lidstrom Larsson, and B. Bjorkman: Waste Manag., 2007, vol. 27, pp. 1335-44.

[31] H. S. Carslaw and J. C. Jaeger: Conduction of Heat in Solids, Clarendon Press, 1959.

[32] I. A. Neacşu, B. Scheichl, H. Rojacz, G. Vorlaufer, M. Varga, H. Schmid, and J. Heiss: Steel Res. Int., 2016, vol. 87, pp. 720-32.

[33] D. Durinck, F. Engström, S. Arnout, J. Heulens, P. T. Jones, B. Björkman, B. Blanpain, and P. Wollants: Resour. Conserv. Recycl., 2008, vol. 52, pp. 1121-31.

[34] D. Turnbull: Contemp. Phys., 1969, vol. 10, pp. 473-88.

[35] H. Yinnon and D. R. Uhlmann: J. Non. Cryst. Solids, 1981, vol. 44, pp. 37-55.

[36] D. R. Uhlmann, H. Yinnon, and C. Y. Fang: in Lunar Planet. Sci. Conf. Proc., 1982, pp. 281-88.

[37] P. Rocabois, J. N. Pontoire, J. Lehmann, and H. Gaye: J. Non. Cryst. Solids, 2001, vol. 282, pp. 98-109.

[38] Y. Q. Sun, H. W. Shen, H. Wang, X. D. Wang, and Z. T. Zhang: Energy, 2014, vol. 76, pp. 761-67. 
Chapter 7. Conclusions and future work 